\title{
Kualitas dan Tingkat Maturasi Oosit Kucing Domestik dari Ovarium yang Disimpan dalam Media dan Waktu yang Berbeda
}

\author{
(QUALITY AND MATURATION RATE OF DOMESTIC CAT OOCYTE \\ FROM OVARY STORED IN DIFFERENT STORAGE TIME AND MEDIUM) \\ Ni Wayan Helpina Widyasanti ${ }^{1}$, Ekayanti Mulyawati Kaiin ${ }^{2}$, \\ Mohamad Agus Setiadi ${ }^{3}$, Ni Wayan Kurniani Karja ${ }^{3^{*}}$ \\ ${ }^{1}$ Program Studi Biologi Reproduksi, Sekolah Pascasarjana, Institut Pertanian Bogor \\ ${ }^{2}$ Laboratorium Bioteknologi Reproduksi Hewan, Pusat Penelitian Bioteknologi, \\ Lembaga Ilmu Pengetahuan Indonesia (LIPI) Cibinong \\ ${ }^{3}$ Divisi Reproduksi dan Kebidanan, Departemen Klinik Reproduksi dan Patologi, \\ Fakultas Kedokteran Hewan,Institut Pertanian Bogor \\ Jl Agathis, Kampus Dramaga IPB, Bogor, Jawa Barat, Indoesiaa 16880 \\ *Email: karja_nwk13@gmail.com
}

\begin{abstract}
This study aims to evaluate the quality and maturation rate of domestic cat oosit from ovary stored in different storage time and media. Ovaries obtained after ovaryohisterectomy were stored in sterile tubes and divided into three groups, namely: 1) without media, 2) containing $\mathrm{NaCl} 0.9 \%$ or 3 ) containing PBS. Then, the ovaries were carried to the laboratory in a thermos containing of $\mathrm{NaCl} 0.9 \% 35-37^{\circ} \mathrm{C}$ or in a cooler bag at $4{ }^{\circ} \mathrm{C}$. The ovaries samples at $4{ }^{\circ} \mathrm{C}$ then were stored in a refrigerator at $4{ }^{\circ} \mathrm{C}$ for 24 and 48 hours. Oocytes from the ovaries which were carried at temperatures of $35-37^{\circ} \mathrm{C}$ was collected within $<6$ hours after arriving in the laboratory. At the end of storage period, the oocytes were collected and evaluated for the quality of oocytes. Furthermore, oocytes were matured in vitro for 24 hours. Based on oocytes morphology, the quality of cat oocytes were not affected by the time and type of media during storage $(\mathrm{P}>0.05)$. The percentage of oocyte form ovaries stored without media or with PBS to reach MII stage were found to decrease $(\mathrm{P}<0.05)$ after 24 hours of storage period. Whereas, the oocytes from ovaries stored with $\mathrm{NaCl} 0.9 \%$ began to decrease $(\mathrm{P}<0.05)$ after 48 hours of storage period. The conclusion of the study was that ovaries storage with or without medium for 48 hours did not affect the morphology of the cat oocyte but affected the level of cat oocyte maturation.
\end{abstract}

Keywords: cat; oocyte; storage time; media

\begin{abstract}
ABSTRAK
Penelitian ini bertujuan untuk mengevaluasi kualitas dan tingkat maturasi oosit kucing domestik yang disimpan dalam waktu dan media yang berbeda. Ovarium yang diperoleh setelah ovaryohisterectomy disimpan dalam tabung steril dan cara penyimpanannya dibagi menjadi tiga perlakuan, yaitu: 1) tanpa media, 2) berisi $\mathrm{NaCl}$ 0,9\% atau 3) berisi PBS. Ovarium tersebut kemudian dibawa ke laboratorium dengan termos yang berisi $\mathrm{NaCl} 0,9 \%$ dengan suhu $35-37^{\circ} \mathrm{C}$ atau dengan cooler box suhu $4^{\circ} \mathrm{C}$. Sampel ovarium suhu $4^{\circ} \mathrm{C}$ kemudian disimpan dalam refrigerator dengan suhu $4^{\circ} \mathrm{C}$ selama 24 dan 48 jam. Oosit dari ovarium yang dibawa dengan suhu suhu $35-37^{\circ} \mathrm{C}$ dikoleksi dalam waktu di bawah enam jam setelah sampai di laboratorium. Pada akhir penyimpanan, oosit dikoleksi dan dievaluasi kualitasnya. Selanjutnya, oosit dimaturasi dan dievaluasi tingkat maturasinya. Hasil dari penelitian ini menunjukkan bahwa berdasarkan morfologinya kualitas oosit kucing tidak dipengaruhi oleh waktu dan jenis media selama penyimpanan $(\mathrm{P}>0,05)$. Tingkat maturasi oosit untuk mencapai tahap MII mulai menurun $(\mathrm{P}<0,05)$ pada ovarium yang disimpan tanpa media maupun dengan PBS pada 24 jam periode penyimpanan, sedangkan oosit yang berasal dari ovarium yang disimpan dengan $\mathrm{NaCl} 0,9 \%$ mulai menurun $(\mathrm{P}<0,05)$ pada 48 jam periode penyimpanan. Simpulan pada penelitian ini adalah penyimpanan ovarium dengan atau tanpa media selama 48 jam tidak memengaruhi morfologi oosit kucing namun memengaruhi tingkat maturasi oosit kucing.
\end{abstract}

Kata-kata kunci: kucing; oosit; waktu penyimpanan; media 


\section{PENDAHULUAN}

Kucing domestik (Felis catus) merupakan anggota famili Felidae yang dapat digunakan sebagai hewan model satwa liar yang terancam punah (Amstislavsky et al., 2012), khususnya pada spesies felid. Menurut IUCN (2018) dari 37 spesies felid yang ada, hanya $F$. catus yang tidak termasuk terancam punah, (CITES, 1984). Kondisi tersebut disebabkan oleh adanya gangguan alam atau akibat campur tangan manusia (Eriani et al., 2013) seperti perburuan, perusakan habitat dan penyakit menular yang menyebabkan terganggunya reproduksi hewan tersebut. Hal ini menyebabkan populasi hewan tersebut semakin berkurang. Untuk mencegah semakin berkurangnya populasi spesies ini diperlukan suatu upaya pelestarian. Beberapa dekade terakhir ini peranan teknologi reproduksi berbantuan berpotensi dalam upaya pelestarian satwa liar yang hampir punah termasuk spesies felid (Holt et al., 2014).

Salah satu teknologi reproduksi berbantuan yang dapat dimanfaatkan untuk meningkatkan jumlah populasi hewan adalah produksi embrio in vitro (PEIV) (Comizzoli et al., 2000). Dengan teknologi PEIV ini, materi genetik dari satwa yang sudah mati masih dapat diselamatkan dan digunakan untuk menghasilkan keturunan. Pada satwa betina yang sudah mati, materi genetik berupa oosit dalam ovariumnya dapat digunakan untuk menghasilkan keturunan baru (Makarevich et al., 2017). Meskipun demikian, keterbatasan laboratorium yang ada ataupun kendala jarak antara lokasi satwa liar langka ditemukan mati dengan laboratorium terdekat menyebabkan oosit yang terdapat dalam ovarium dari hewan yang mati tersebut tidak dapat segera dikoleksi dan diproses lebih lanjut. Oleh karena itu, kajian tentang metode penyimpanan ovarium selama transportasi untuk tetap dapat menjaga kualitas oosit di dalamnya menjadi faktor penting.

Keberhasilan dari teknologi PEIV sangat dipengaruhi oleh kualitas oosit yang digunakan (Krisher, 2004). Kualitas oosit dipengaruhi oleh penanganan ovarium selama di luar tubuh hewan sampai oosit dikoleksi. Rentang waktu ini merupakan titik kritis karena menjadi penentu kualitas oosit yang akan diperoleh (Febretrisiana dan Pamungkas, 2017). Setelah kematian hewan, hilangnya pasokan darah menyebabkan oksigen dan energi untuk ovarium hilang sehingga ovarium mengalami iskemia dan reoksigenasi (Lopes et al., 2009; Wongsrikeao et al., 2005). Kurangnya oksigen dalam ovarium menyebabkan terjadinya perubahan metabolisme, yaitu dari aerobik menjadi anaerobik yang kemudian menghasilkan asam laktat (Wongsrikeao et al., 2005). Dalam jaringan ovarium juga terjadi kegagalan produksi adenosin triphosphat (ATP) dan kegagalan metabolisme pada mitokondria akibat terhentinya penyimpanan energi dalam sel (Deb et al., 2010). Hasil akhir akibat penurunan ATP berupa fosfat anorganik yang berikatan dengan $\mathrm{H} \mathrm{O}$ yang selanjutnya menjadi asam fosfat. Produk asam laktat dan asam fosfat yang terakumulasi dalam ovarium mengakibatkan penurunan $\mathrm{pH}$ folikel (asidosis) yang apabila terjadi secara terus menerus dapat menurunkan kualitas oosit dan meningkatkan fragmentasi DNA pada oosit (Wongsrikeao et al., 2005).

Selama transportasi terdapat beberapa hal yang perlu diperhatikan, yaitu: suhu (Febretrisiana et al., 2015), waktu (Tulake et al., 2014) dan media transport (Barberino et al., 2018). Penyimpanan ovarium kucing yang umum dilakukan yaitu penyimpanan dengan suhu hangat atau mendekati suhu tubuh $\left(37^{\circ} \mathrm{C}\right)$ (Evecen et al., 2018 ), suhu ruang $\left(23-25^{\circ} \mathrm{C}\right)$ (Naoi et al., 2007) dan suhu dingin $\left(4^{\circ} \mathrm{C}\right)$ (Piras et al., 2018). Penggunaan medium transportasi pada suhu $37^{\circ} \mathrm{C}$ bertujuan untuk menghindari perbedaan suhu pada ovarium sebelum dan sesudah di luar tubuh dengan harapan kualitas oosit yang baik dapat dipertahankan (Taylor, $2006)$, sedangkan pada suhu dingin $\left(4^{\circ} \mathrm{C}\right)$ metabolisme sel dapat diperlambat (Silva et al., 2000). Oosit kucing memiliki kemampuan yang unik yaitu dapat disimpan pada suhu $4^{\circ} \mathrm{C}$ (Luu et al., 2014; Anna et al., 2018) dan mampu mencapai metaphase II (MII) secara in vitro, sedangkan pada suhu ruang hasilnya lebih rendah (Wlodarczyk et al., 2009). Oleh karena itu, suhu $4^{\circ} \mathrm{C}$ lebih direkomendasikan untuk menyelamatkan oosit dari ovarium felid yang terancam punah setelah kematian mendadak atau pasca ovariohisterectomy (Naoi et al., 2007).

Media transport ovarium dapat menggunakan phosphate buffer saline (PBS) atau menggunakan $\mathrm{NaCl}$ 0,9\% (Gordon, 2003) memberikan hasil yang bervariasi pada kemampuan oosit untuk mencapai MII. Wlodarczyk et al. (2009) dan Evecen et al. (2018) menemukan penurunan yang nyata pada persentasi oosit kucing yang mencapai MII setelah penyimpanan ovarium dalam $\mathrm{NaCl} 0,9 \%$ pada suhu $4^{\circ} \mathrm{C}$ selama 24 jam, sedangkan 
menurut Evecen et al. (2009) persentase MII oosit kucing yang disimpan un secara nyata pada penyimpanan ovarium selama 48 jam. Demikian juga pada media PBS, Eriani et al. (2018) melaporkan bahwa persentase oosit kucing yang mencapai MII menurun secara nyata pada penyimpanan ovarium dalam PBS selama 24 jam, sedangkan menurut Piras et al. (2018) persentase MII pada oosit kucing menurun secara nyata pada penyimpanan ovarium dalam PBS selama 72 jam. Oleh karena itu, penelitian ini bertujuan untuk mengevaluasi kualitas dan tingkat maturasi oosit kucing domestik yang dikoleksi dari ovarium setelah disimpan pada periode waktu penyimpanan dan media yang berbeda.

\section{METODE PENELITIAN}

\section{Koleksi dan Penyimpanan Ovarium}

Ovarium diperoleh pasca ovaryohisterectomy dari klinik hewan di sekitar Kota Bogor dan Kabupaten Bogor. Ovarium yang diperoleh dibagi menjadi tiga perlakuan yaitu ovarium disimpan dalam tube steril: 1) tanpa media, 2) berisi $\mathrm{NaCl}$ 0,9\%, atau 3) berisi PBS. Kedua media transport tersebut ditambahkan antibiotik $100 \mathrm{IU} / \mathrm{mL}$ penisilin (Sigma-Aldrich, Inc, P-4687) dan 0,1 mg/mL streptomisin (Sigma-Aldrich. Inc, S-9137). Spesimen ovarium kemudian dibawa ke laboratorium dengan termos yang berisi $\mathrm{NaCl}$ 0,9\% dengan suhu 35 $37^{\circ} \mathrm{C}$ atau dengan cooler bag dengan suhu $4^{\circ} \mathrm{C}$. Spesimen ovarium yang ditranspor pada suhu $4^{\circ} \mathrm{C}$ setelah sampai di laboratorium segera disimpan dalam refrigerator pada suhu $4^{\circ} \mathrm{C}$ selama 24 dan 48 jam, sedangkan ovarium yang dibawa dengan suhu suhu $35-37^{\circ} \mathrm{C}$ segera diproses untuk koleksi dan maturasi dikoleksi dalam waktu kurang dari enam jam setelah ovaryohisterectomy.

\section{Koleksi Oosit}

Metode yang digunakan untuk koleksi oosit kucing pada penelitian ini menggunakan metode slicing seperti yang dilaporkan oleh Karja et al. (2002) dengan sedikit modifikasi Ovarium dicacah bagian permukaannya untuk melepaskan oosit dari folikel di dalam cawan petri yang berisi PBS yang sudah disuplementasi 0,3\% bovine serum albumin (BSA) (Sigma-Aldrich. Inc, P-4687), 100 IU/mL penicillin dan $0,1 \mathrm{mg} / \mathrm{mL}$ streptomycin. Oosit yang telah dikoleksi, kemudian dikelompokkan berdasarkan morfologinya dengan melihat lapisan sel kumulus dan gambaran sitoplasmanya di bawah mikroskop stereo (Olympus SZ51, Philippines). Berdasarkan jumlah lapisan sel kumulus dan kehomogenan sitoplasma, oosit yang diperoleh dibagi menjadi empat yaitu: kualitas A, B, C dan D. Oosit dengan kualitas A mempunyai sel kumulus lebih dari lima lapis dan memiliki sitoplasma yang homogen dan berwarna hitam. Oosit kualitas B dilapisi sel kumulus kurang dari lima lapis, sitoplasma berwarna hitam dan homogen. Oosit kualitas C memiliki sedikit sel kumulus, sitoplasma tidak homogen dan zona pelusida masih terlihat. Oosit kualitas D memiliki sitoplasma transparan dan sel kumulus hampir tidak ada atau tidak ada sama sekali (Gordon, 2003).

\section{Maturasi Oosit secara in vitro}

Pada penelitian ini oosit yang dimaturasi hanya oosit kualitas A dan B karena memiliki kompetensi untuk mencapai metaphase II (MII) saat dimaturasi secara in vitro Davachi et al. (2011). Oosit tersebut kemudian dimaturasi selama 24 jam dalam drop berisi $100 \mu \mathrm{L}$ medium maturasi yang berisi 3-10 oosit dan ditutup dengan mineral oil (Sigma, USA). Media maturasi terdiri dari tissue culture medium-199 (TCM-199) (Gibco, Grand Island, NY, USA) yang disuplementasi dengan bovine serum albumin $0,4 \%$ (BSA, Sigma), 0,1 IU/mL follicle stimulating hormone (FSH) (Folltropin-V, Vetoquinol), $10 \mathrm{IU} / \mathrm{mL}$ human chorionic gonadotropin (HCG) (Chorulon ${ }^{\mathrm{TM}}$, MSD Animal Health) dan $50 \mu \mathrm{g} / \mathrm{mL}$ gentamisin (SigmaAldrich, USA). Media maturasi yang digunakan terlebih dahulu diekuilibrasi minimal selama 2 jam pada suhu dan kadar $\mathrm{CO}_{2}$ yang sama dengan proses maturasi oosit yaitu $38,5^{\circ} \mathrm{C}$ dengan kadar $\mathrm{CO}_{2}$ sebanyak 5\% (Karja et al., 2002).

\section{Evaluasi Tingkat Maturasi Inti Oosit In Vitro}

Evaluasi tingkat pematangan oosit dilakukan dengan pewarnaan aceto-orcein (Karja et al., 2002). Pada akhir periode maturasi in vitro, oosit didenudasi dengan cara dipipet berulang-ulang dengan bantuan enzim hyaluronidase 0,25\% sampai sel kumulus lepas. Oosit yang sudah terdenudasi dibilas dan diletakkan pada drop berisi PBS yang disuplementasi BSA 0,4\% di atas gelas objek yang kedua sisinya telah diberi bantalan paraffin dan vaselin dengan perbandingan (1:9). Oosit 
kemudian ditutup menggunakan cover glass secara perlahan agar oosit tidak pecah sambil meratakan paraffin dan vaseline agar menempel sempurna pada gelas objek. Preparat selanjutnya difiksasi dalam larutan acetic acid: ethanol (1:3) selama 48-72 jam dan diwarnai dengan aceto-orcein $2 \%$ dan dievaluasi dengan menggunakan mikroskop fase kontras (Olympus IX 70, Olympus Co, Tokyo, Japan). Status inti oosit dikelompokkan menurut Gordon (2003) menjadi tahap germinal vesicle $(\mathrm{GV})$, germinal vesicle breakdown (GVBD), metaphase I, anaphase/telophase (A/T) dan metaphase II (MII).

\section{Analisis Statistika}

Penelitian ini menggunakan rancangan acak lengkap (RAL) dengan sembilan perlakuan. Jumlah ulangan minimal empat kali dan jumlah sampel minimal 50 oosit tiap perlakuan. Data dianalisis dengan sidik ragam satu arah dengan tingkat kepercayaan 95\% dan apabila terdapat perbedaan yang nyata antar perlakuan, dilanjutkan dengan uji jarak berganda Duncan. Data diolah menggunakan program SPSS versi 22.0.

\section{HASIL DAN PEMBAHASAN}

Keberhasilan PEIV sangat dipengaruhi oleh kualitas oosit sebelum dimaturasi. Oosit kucing yang dikoleksi dari ovarium pascapenyimpanan dalam berbagai media berdasarkan morfologinya mempunyai kualitas yang bervariasi seperti yang ditunjukkan pada Gambar 1.

Menurut Gordon (2003), oosit yang baik adalah oosit yang memiliki sitoplasma yang homogen dan zona pelusida dikelilingi oleh sel kumulus yang rapat. Sel kumulus memengaruhi proses maturasi oosit dan pematangan sitoplasma serta berpengaruh terhadap perkembangan setelah fertilisasi (Abeydeera, 2002). Menurut Davachi et al. (2011) oosit yang memiliki sel kumulus 3-5 lapis berpengaruh terhadap tingkat ekspansi sel kumulus secara maksimum serta mendukung oosit untuk mencapai tahap MII karena sel kumulus berperan dalam memasok nutrisi bagi oosit. Oleh karena itu, oosit yang dipakai untuk proses maturasi in vitro pada penelitian ini adalah oosit dengan kualitas A dan B karena memiliki lapisan sel kumulus 3-5 lapis atau lebih dengan sitoplasma yang homogen berwarna hitam.

Berdasarkan jumlah lapisan sel kumulus dan kehomogenan sitoplasma, oosit kucing yang dikoleksi dari ovarium yang disimpan pada suhu $4^{\circ} \mathrm{C}$ dengan atau tanpa media dibagi menjadi empat kriteria seperti yang disajikan pada data di Tabel 1.

Hasil penelitian yang disajikan pada Tabel 1 menunjukkan bahwa kualitas oosit kucing berdasarkan morfologinya tidak dipengaruhi oleh waktu penyimanan baik disimpan dengan

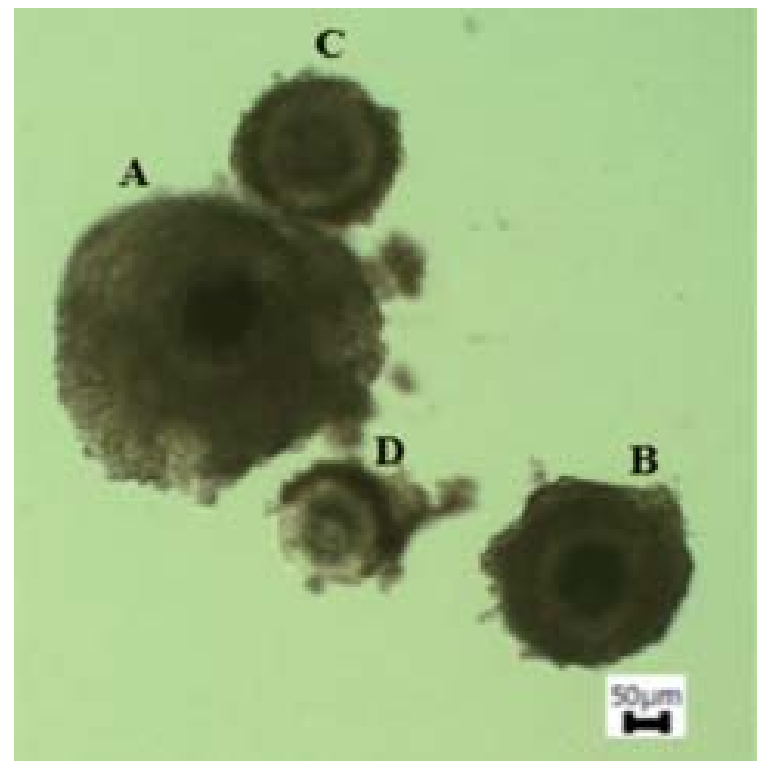

Gambar 1. Kualitas oosit kucing kualitas A, B, C dan D

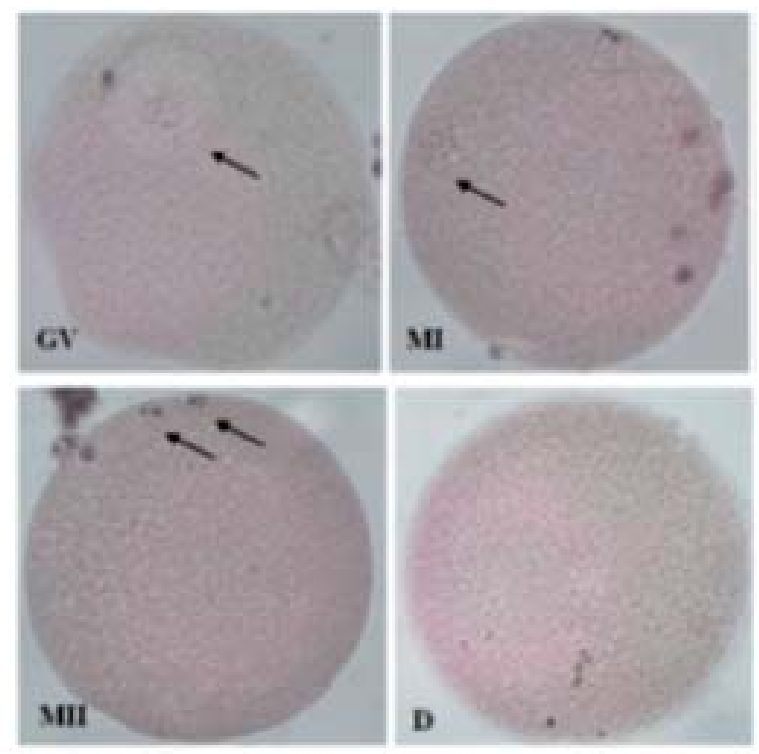

Gambar 2. Status inti oosit kucing pada perbesaran 20x10, tanda panah menunjukkan status inti pada tahap GV: germinal vesicle, MI: metaphase I, MII: metaphase II, D: degenerasi 
Tabel 1. Kualitas oosit dari ovarium yang disimpan pada media transportasi dan waktu yang Berbeda

\begin{tabular}{|c|c|c|c|c|c|c|}
\hline \multirow{2}{*}{$\begin{array}{l}\text { Waktu } \\
\text { (jam) }\end{array}$} & \multirow{2}{*}{$\begin{array}{l}\text { Jenis } \\
\text { Media }\end{array}$} & \multirow{2}{*}{$\begin{array}{c}\text { Jumlah } \\
\text { Oosit }\end{array}$} & \multicolumn{4}{|c|}{ Persentase $\pm \mathrm{SD}(\mathrm{n})$ oosit dengan kualitas } \\
\hline & & & $\mathrm{A}$ & B & $\mathrm{C}$ & D \\
\hline \multirow[t]{3}{*}{$<6$} & Tanpa Media & 391 & $7 \pm 4,4(26)$ & $22,4 \pm 7,4(84)$ & $45,6 \pm 8,4(187)$ & $24,9 \pm 9,4(94)$ \\
\hline & $\mathrm{NaCl} 0,9 \%$ & 295 & $7,2 \pm 3,2(18)$ & $20,6 \pm 19(52)$ & $35,6 \pm 15,2(111)$ & $36,6 \pm 6,6(114)$ \\
\hline & PBS & 381 & $7,8 \pm 2,2(27)$ & $20,5 \pm 3,3(80)$ & $45 \pm 8,1(171)$ & $26,7 \pm 4,6(103)$ \\
\hline \multirow[t]{3}{*}{24} & Tanpa Media & 300 & $12 \pm 6,2(32)$ & $16,8 \pm 4(53)$ & $30,7 \pm 13,6(99)$ & $40,4 \pm 13,6(116)$ \\
\hline & $\mathrm{NaCl} 0,9 \%$ & 438 & $3,7 \pm 2,2(16)$ & $15,1 \pm 12,2(63)$ & $49,7 \pm 6,6(218)$ & $31,5 \pm 9,6(141)$ \\
\hline & PBS & 571 & $6,1 \pm 4,2(33)$ & $17,5 \pm 6,9(103)$ & $39,1 \pm 10,2(219)$ & $37,3 \pm 11,8(216)$ \\
\hline \multirow[t]{3}{*}{48} & Tanpa Media & 404 & $4,4 \pm 2,4(17)$ & $16,2 \pm 2,6(61)$ & $39,9 \pm 11,7(168)$ & $39,5 \pm 12,8(158)$ \\
\hline & $\mathrm{NaCl} 0,9 \%$ & 403 & $5,2 \pm 2,9(21)$ & $12,5 \pm 2,6(51)$ & $39,9 \pm 11(152)$ & $42,5 \pm 10,1(179)$ \\
\hline & PBS & 499 & $7,1 \pm 5(34)$ & $14,6 \pm 5,4(73)$ & $36,6 \pm 9(182)$ & $41,7 \pm 14,5(210)$ \\
\hline
\end{tabular}

Keterangan: Perlakuan <6 jam disimpan pada suhu $35-37{ }^{\circ} \mathrm{C}, 24$ dan 48 jam disimpan pada suhu $4{ }^{\circ} \mathrm{C}$. A: Oosit memiliki sel kumulus lebih dari lima lapis dan memiliki sitoplasma yang homogen dan berwarna hitam; B: Oosit yang dilapisi sel kumulus kurang dari lima lapis, sitoplasma berwarna hitam dan homogen.; C: Oosit yang memiliki sedikit sel kumulus, sitoplasma tidak homogen dan zona pelusida masih terlihat; D: Oosit yang memiliki sitoplasma transparan dan sel kumulus hampir tidak ada atau tidak ada sama sekali.

atau tanpa media $(\mathrm{P}>0,05)$. Data pada penelitian ini mengindikasikan bahwa ovarium yang disimpan pada suhu $4^{\circ} \mathrm{C}$ disimpan dengan atau tanpa media mampu mempertahankan kualitas oosit sampai 48 jam pascapenyimpanan. Eriani et al. (2018) melaporkan bahwa walaupun preservasi ovarium kucing pada suhu $4^{\circ} \mathrm{C}$ selama 48 jam dalam PBS tidak memengaruhi kualitas oosit di dalam folikel sekunder, tersier maupun folikel de Graf sehingga diduga kualitas oosit yang diperoleh pada penelitian ini tidak berbeda antar perlakuan. Phosphate buffer saline mempunyai komposisi bahan yang lebih kompleks dari $\mathrm{NaCl}$ 0,9\%, namun kedua media tersebut merupakan larutan fisiologis bersifat isotonis (Dave dan Ghaly, 2011) yang mampu memperlambat terjadinya autolisis, sehingga memiliki kemampuan yang sama dalam mempertahankan kualitas oosit. Hal senada juga dilaporkan oleh Gencoglu et al. (2011) yang menyatakan bahwa larutan fisiologis dapat mengurangi kerusakan sel akibat tekanan osmotik intra dan ekstra sel yang tidak seimbang.

Pada penelliti ini ditemukan, kualitas oosit dari ovarium kucing yang disimpan tanpa media secara morfologi tidak berbeda dengan oosit dari ovarium yang disimpan dengan media $\mathrm{NaCl}$ $0,9 \%$ atau PBS. Ovarium kucing yang disimpan tanpa media kemungkinan masih mampu mempertahankan osmolaritas intra dan ekstraseluler hingga 48 jam pada suhu $4^{\circ} \mathrm{C}$ sehingga mencegah keadaan hiperosmolar di dalam sel (Hartanto, 2007). Selain itu, pada suhu $4^{\circ} \mathrm{C}$ gerak termal molekul akan melambat dan komplek antara enzim dengan substrat dapat diminimalkan, sehingga kerja enzim tidak optimal dalam melaksanakan reaksi metabolisme. Akibatnya, kebutuhan nutrisi dan oksigen di dalam ovarium dapat dikurangi selama penyimpanan serta dapat menghambat penumpukan asam laktat (Petrucci et al., 2010). Oleh karena itu, pada penelitian ini persentase perolehan oosit berdasarkan morfologinya tidak berbeda selama masa penyimpanan sampai 48 jam.

Selain kualitas oosit, keberhasilan PEIV juga sangat dipengaruhi oleh tingkat maturasi oosit karena hanya oosit yang mencapai MII saja yang dapat difertilisasi dan mampu berkembang mencapai embrio (Setiadi dan Karja, 2013). Gambaran tingkat maturasi oosit pada tahap GV, MI dan MII setelah maturasi in vitro disajikan pada Gambar 2. Oosit pada tahap GV ditandai dengan membran inti dan nukleous terlihat jelas serta masih menyatu di dalam vesicle. Pada MI, kromosom homolog terlihat berderet dibidang ekuator. Pada MII ditandai adanya badan polar I dan susunan kromoson sama dengan MI (Gordon, 2003). Oosit yang mengalami degenerasi merupakan oosit yang memiliki abnormalitas konfigurasi, kromatin tersebar pada seluruh bagian oosit atau tidak terdapat kromatin (Alm et al., 2005). 
Data pada Tabel 2 merupakan persentase tingkat maturasi oosit kucing domestik yang dikoleksi dari ovarium yang disimpan pada media transport dan waktu yang berbeda. Hasil penelitian menunjukkan bahwa walaupun waktu dan media penyimpanan tidak memengaruhi kualitas oosit berdasarkan morfologi tetapi memengaruhi kompetensi oosit untuk mencapai MII secara in vitro. Kemampuan oosit dari ovarium yang disimpan dengan atau tanpa media untuk berkembang mencapai tahap MII tidak berbeda antar perlakuan waktu penyimpanan yang sama $(\mathrm{P}>0,05)$. Kemampuan tersebut menurun dengan bertambahnya periode penyimpanan. Persentase oosit yang mencapai MII sudah mulai menurun $(\mathrm{P}<0,05)$ setetah 24 jam penyimpanan pada oosit yang disimpan tanpa media atau dengan PBS. Persentasi oosit dari ovarium yang disimpan pada $\mathrm{NaCl} 0,9 \%$ dalam mencapai MII ditemukan menurun $(\mathrm{P}<0,05)$ secara nyata setelah 48 jam pascapenyimpanan. Namun, tidak ditemukan adanya perbedaan persentasi MII antara periode waktu penyimpanan selama 24 dengan 48 jam $(\mathrm{P}<0,05)$. Hal ini diduga disebabkan oosit dari ovarium yang disimpan tanpa media selama 24 jam tetap bermetabolisme meskipun lambat dan menghasilkan asam laktat yang merupakan hasil dari proses glikolisis anaerob (Moraes et al., 2008). Ovarium yang disimpan tanpa media tidak memiliki larutan buffer yang cukup untuk menyeimbangkan $\mathrm{CO}_{2}$ dan asam laktat hasil metabolisme sel (Pellegrin et al., 2008).
Akibatnya, kondisi lingkungan semakin asam seiring dengan bertambahnya waktu penyimpanan (asidosis) yang mengakibatkan fragmentasi DNA oosit (Wongsrikeao et al., 2005).

Pada ovarium yang disimpan dalam PBS meskipun mengandung buffer dan berbagai zat nutrisi, juga mengalami penurunan persentase MII pada penyimpanan $24 \mathrm{jam}$. Hal ini diduga disebabkan PBS yang digunakan dalam penelitian ini mengandung asam piruvat. Asam piruvat merupakan hasil dari perombakan glukosa. Dalam kondisi aerob, asam piruvat dikonversi menjadi asetil CoA untuk masuk ke siklus Krebs menghasilkan energi (Phypers dan Pierce, 2006), sedangkan pada penelitian ini ovarium berada dalam kondisi anaerob sejak ovarium berada di luar tubuh. Pada kondisi anaerob pembentukan energi melalui metabolisme piruvat terhambat, oksidasi aerobic dalam siklus Krebs terhambat (blokade) dan asam piruvat akhirnya dikonversi menjadi asam laktat yang dibantu oleh enzim laktat dehidrogenase (LDH) (Phypers dan Pierce, 2006; Poedjiadi dan Supriyanti, 2012). Selain itu, tambahan asam juga didapatkan dari kondisi ovarium itu sendiri sejak ovarium berada di luar tubuh, yaitu menghasilkan produk berupa asam laktat dan asam fosfat yang terakumulasi dalam ovarium. Hal ini menyebabkan penurunan $\mathrm{pH}$ folikel (asidosis) yang dapat meningkatkan fragmentasi DNA pada oosit (Wongsrikeao et al., 2005).

Kemampuan oosit mencapai MII dengan

Tabel 2. Tingkat maturasi oosit kucing dari ovarium yang disimpan dalam waktu dan media yang berbeda

\begin{tabular}{lcccccc}
\hline \multirow{2}{*}{$\begin{array}{l}\text { Waktu } \\
\text { (jam) }\end{array}$} & Jenis & Media & Jumlah & \multicolumn{5}{c}{ Persentase \pm SD(n) oosit dengan kualitas A-B } \\
\cline { 3 - 7 } & & Oosit & \multicolumn{6}{c}{ GV } & MI & MII & D \\
\hline \multirow{2}{*}{$<6$} & Tanpa Media & 107 & $8,5 \pm 5,4(9)$ & $5,9 \pm 8,3(7)$ & $74,4 \pm 8,2(79)^{\mathrm{a}}$ & $11,2 \pm 9,1(12)$ \\
& NaCl 0,9\% & 52 & $12,5 \pm 14,9(9)$ & $7,3 \pm 7,8(6)$ & $71,8 \pm 8,8(63)^{\mathrm{ab}}$ & $8,5 \pm 8,7(7)$ \\
& PBS & 51 & $13,1 \pm 11(6)$ & $1,5 \pm 3,7(1)$ & $69,2 \pm 13,1(30)^{\mathrm{ab}}$ & $16,2 \pm 17,2(6)$ \\
24 & Tanpa Media & 94 & $7,9 \pm 11(7)$ & $14,8 \pm 8,2(14)$ & $58,2 \pm 9,9(55)^{\mathrm{bc}}$ & $19,2 \pm 8,1(18)$ \\
& NaCl 0,9\% & 75 & $14,4 \pm 10,3(10)$ & $11,9 \pm 8,9(7)$ & $59,9 \pm 5,7(45)^{\mathrm{bc}}$ & $13,8 \pm 13,7(13)$ \\
& PBS & 74 & $9,5 \pm 7,5(7)$ & $16,5 \pm 13,7(13)$ & $48,5 \pm 15,8(31)^{\mathrm{c}}$ & $25,6 \pm 21,2(23)$ \\
48 & Tanpa Media & 80 & $9,5 \pm 7,2(8)$ & $15,4 \pm 13,3(14)$ & $49,8 \pm 6,7(39)^{\mathrm{c}}$ & $25,3 \pm 10,3(19)$ \\
& NaCl 0,9\% & 92 & $11,7 \pm 15,6(13)$ & $17,8 \pm 13,8(19)$ & $45,4 \pm 14,4(38)^{\mathrm{c}}$ & $25,1 \pm 18,6(22)$ \\
& PBS & 68 & $15,9 \pm 12,3(14)$ & $17,8 \pm 13,6(17)$ & $47,9 \pm 14,3(46)^{\mathrm{c}}$ & $18,5 \pm 12,6(17)$ \\
\hline
\end{tabular}

Keterangan: GV: germinal vesicle, MI:metaphase I, MII: metaphase II, D: degerasi, Perlakuan $<6$ jam disimpan pada suhu $35-37^{\circ} \mathrm{C}$, 24 dan 48 jam disimpan pada suhu $4{ }^{\circ} \mathrm{C}$, Superskrip yang berbeda (a,b,c) dalam kolom yang sama menunjukkan ada perbedaan yang nyata pada setiap perlakuan $(P<0,05)$ 
atau tanpa media tidak berbeda $(\mathrm{P}>0,05)$ pada penyimpanan ovarium selama 24 ataupun 48 jam. Penurunan kemampuan oosit mencapai MII pada penyimpanan ovarium disebabkan adanya penyusunan kembali kumparan meiotik dari mikrotubulus. Menurut Wiedemann et al. (2013) pada suhu $20^{\circ} \mathrm{C}$ atau $4^{\circ} \mathrm{C}$ akan terjadi depolimerisasi mikrotubul, namun kumparan meiotik mampu terakit kembali (reversible) saat oosit sapi diinkubasi pada suhu $37^{\circ} \mathrm{C}$ selama 60 menit. Oosit kucing memiliki kemampuan yang unik yaitu dapat disimpan pada suhu $4^{\circ} \mathrm{C}$ (Luu et al., 2014) dan mampu mencapai MII secara in vitro (Anna et al., 2018). Hasil penelitian Piras et al. (2018) menunjukkan bahwa penyimpanan ovarium kucing selama 24 jam pada suhu $4{ }^{\circ} \mathrm{C}$ tidak memengaruhi morfologi dan integritas DNA folikel preantral. Didukung oleh penelitian Eriani (2018) yang melaporkan bahwa preservasi ovarium pada suhu $4^{\circ} \mathrm{C}$ selama 48 jam dapat mempertahankan fungsi biologi oosit untuk mencapai tahap metaphase II (MII) secara in vitro fertiliztion (IVM). Persentase oosit yang mengalami degenerasi setelah maturasi in vitro pada penelitian ini juga ditemukan tidak berbeda antar kelompok perlakuan selama penyimanan 48 jam. Data ini mengindikasikan bahwa waktu dan jenis media penyimpanan tidak memengaruhi persentasi oosit yang mengalami degenerasi selama 48 jam penyimpanan.

\section{SIMPULAN}

Berdasarkan hasil penelitian dapat disimpulkan bahwa penyimpanan ovarium dengan atau tanpa medium selama 48 jam tidak memengaruhi morfologi oosit kucing namun memengaruhi tingkat maturasi inti oosit kucing.

\section{SARAN}

Perlu dilakukan penelitian lebih lanjut pada kerusakan tingkat seluler akibat penyimpanan dan transportasi beserta kemampuan oosit untuk berkembang menjadi embrio setelah difertilisasi.

\section{DAFTAR PUSTAKA}

Abeydeera LR. 2002. In vitro production of embryos in swine. Theriogenology 57: 256273.
Alm H, Torner H, Löhrke B, Viergutz T, Ghoneim IM, Kanitz W. 2005. Bovine blastocystdevelopment rate in vitro is influenced by selection of oocytes by brilliant cresyl blue staining before IVM as indicator for glucose-6-phosphate dehydrogenase activity. Theriogenology 63: 2194-2205.

Amstislavsky S, Lindeberg H, Luvoni G. 2012. Reproductive technologies relevant to the genome resource bank in Carnivora. Reprod Domest Anim 47: 164-175.

Anna RP, Giovanni PB, Federica A, Laura F, Maria TZ, Salvatore P, Sergio DG, Elisabetta A, Daniela B, Sergio L, Luisa B. 2018. Structure of preantral follicles, oxidative status and developmental competence of in vitro matured oocytes after ovary storage at $4 \mathrm{C}$ in the domestic cat model. Reproductive Biology and Endocrinology 16(1): 1-14.

Barberino RS, Silva JRV, Figueiredo JR, Matos MHT. 2018. Transport of domestic and wild animal ovaries: a review of the effects of medium, temperature, and periods of storage on follicular viability. Biopreservation and Biobanking 17(1): 1-7.

CITES (Convention of International Trade in Endangered Spesies).1984. International trade endangered spesies of wild flora and fauna. Act Cod Fed Reg Part. 23.

Comizzoli P, Mermillod P, Mauget R. 2000. Reproductive biotechnologies for endangered mammalian species. Reproduction Nutrition Development 40: 493-504.

Davachi D, Kohram H, Zainoaldini S. 2011. Cumulus cell layers as a critical factor in meiotic competence and cumulus expansion of ovine oocytes. Small Rumin Res 102(1): 37-42.

Dave D, Ghaly AE. 2011. Meat spoilage mechanisms and preservation techniques: A critical review. Am J Agricult Biol Sci 6(4): 486-510.

Deb P, Sharma S, Hassan KM. 2010. Pathophysiologic mechanisms of acute ischemic stroke: an overview with emphasis on therapeutic significance beyond thrombolysis. Pathophysiology 17: 197-218.

Eriani K, Sukra Y, Boediono A, Djuwita I, Sumarsono SH. 2013. Produksi embrio kucing secara in vitro dari spermatozoa 
hasil preservasi melalui fertilisasi mikro. $J$ Kedokteran Hewan 7(1): 37-42.

Eriani K, Boediono A, Sumarsono SH, Azhar A. 2018. Utilization of oocytes collected from preserved ovarian for in vitro production of cat embryos. Biosaintifika 10(1): 160-168.

Evecen M, Cirit U, Demir K, Karaman E, Hamzaoglu AI, Bakýrer G. 2009. Developmental competence of domestic cat oocytes from ovaries stored at various durations at $4 æ \% \mathrm{C}$ temperature. Animal Reproduction Science 116: 169-172.

Evecen M, Demir K, Arici R, Yaðcioðlu S, Ersoy N, Copkun N, Armutak E, Üvez A, Gürevin EG, Eser A, Atalla H, Kemal AK, Pabuccuoðlu S, Birler S. 2018. Effects of ovary transport and storage temperature on in vitro maturation and cumulus cell apoptosis rates in cat oocytes. Kafkas Univ Vet Fak Derg 24(2): 301-306.

Febretrisiana A, Setiadi MA, Karja NWK. 2015. Nuclear maturation rate of sheep oocyte in vitro: Effect of storage duration and ovary temperature. J Indonesian Trop Anim Agric 40: 93-99.

Febretrisiana A, Pamungkas FA. 2017. Pemanfaatan ovarium yang berasal dari rumah potong hewan sebagai sumber materi genetik. Wartazoa 27(4): 159-166.

Gencoglu A, Camacho-Alanis F, Nguyen VT, Nakano A, Ros A, Minerick AR. 2011. Quantification of $\mathrm{pH}$ gradients and implications in insulator-based dielectrophoresis of biomolecules. Electrophoresis 32: 24362447.

Gordon I. 2003. Laboratory Production of Cattle Embryos Ed 2. London, GB. CABI Pub. Hlm. $134 ; 143-144 ; 382$.

Hartanto WW. 2007. Terapi Cairan dan Elektrolit Perioperatif. Bandung, ID: Bagian Farmakologi Klinik dan Terapeutik. Sumedang. Fakultas Kedokteran, Universitas Padjajaran. Hlm. 8.

Holt WV, Brown JL, Comizzoli P. 2014. Reproductive science as an essential component of conservation biology. Adv Exp Med Biol 753: 3-14.

IUCN (International Union for Conservation of Nature). 2018. The IUCN Red List of
Threatened Species.Version 2018-1. http:// www.iucnredlist.org [29 November 2019].

Karja NWK, Otoi T, Murakami M, Fahrudin M, Suzuki T. 2002. In vitro maturation, fertilization and development of domestic cat oocytes recovered from ovaries collected at three stages of the reproductive cycle. Theriogenology 57: 2289-2298.

Krisher RL. 2004. The effect of oocyte quality on development. J Anim Sci 82: E14E23.

Lopes CAP, Santos RR, Celestino JJH, Melo MAP, Chaves RN, Campello CC, Silva JRV, Bao SN, Jewgenow K, Figueiredo JR. 2009. Short-term preservation of canine preantral follicles: Effects of temperature, medium, and time. Animal Reproduction Science 115(1): 201-214.

Luu VV, Namula Z, Do LT, Sato Y, Taniguchi M, Karja NW, Otoi T. 2014. Nuclear status and DNA fragmentation of oocytes from porcine, bovine and feline ovaries stored at 4 degrees $\mathrm{C}$ for 5 days. Cryo Letters 35: 48-53.

Makarevich A, Foldesiova M, Olexikova L, Kubovicova E, Chrenek P. 2017. Possibilities of cattle ovarian tissue conservation: a minireview. Slovak J Anim Sci 50(3): 128-133.

Moraes AM, Mendonca RZ, Suazo CAT. 2008. Culture Media for Animal Cells. Di dalam: Castilho LR, Moraes AM, Agusto EFP, Butler M, editor. Animal Cells Technology: From Biopharmacenticals to Gene Therapy. Amilton Park Abingdon (UK), Taylor and Francis Group. Hlm. 111-128.

Naoi H, Otoi T, Shimamura T, Karja NW, Agung B, Shimizu R, Taniguchi M, Nagai T . 2007. Developmental competence of cat oocytes from ovaries stored at various temperature for 24 h. J Reprod Dev 53: 271277.

Pellegrin MP, Pinto RCV, Castilho LDR. 2008. Mechanism Of Cells Proliferation and Cell Death In Animal Cell Culture In Vitro. Dalam: Castilho LR, Moraes AM, Agusto EFP, Butler M, editor. Animal Cells Technology: From Biopharmacenticals to Gene Therapy. Amilton Park Abingdon (UK), Taylor and Francis Group. Hlm. 147179. 
Petrucci RH, Herring FG, Madura JD. 2010. General Chemistry Prinsiple and Modern Application Ed 10. Canada, CA. Pearson.

Phypers B, Pierce JMT. 2006. Lactate physiology in health and disease. British Journal of Anaesthesia 6(3): 128-132.

Piras AR, BP Giovanni, Ariu F, Falchi L, Zedda MT, Pau S, Gadau SD, Antuofermo E, Bebbere D, Ledda S, Bogliolo L. 2018. Structure of preantral follicles, oxidative status and developmental competence of in vitro matured oocytes after ovary storage at $4{ }^{\circ} \mathrm{C}$ in the domestic cat model. Reproductive Biology and Endocrinology 16(1): 1-14.

Poedjiadi A, Supriyanti FMT. 2012. Dasar-Dasar Biokimia Ed 2. Jakarta. UI-Press. Hlm. 254-255

Setiadi MA, Karja NWK. 2013. Tingkat perkembangan awal embrio sapi in vitro menggunakan media tunggal berbahan dasar tissue culture medium (TCM) 199. Jurnal Kedokteran Hewan 7(2): 150-154.

Silva J, Lucci C, Carvalho F, Báo S, Costa S, Santos R, Figueiredo J. 2000. Effect of coconut water and Braun-Collins solutions at different temperatures and incubation times on the morphology of goat preantral follicles preserved in vitro. Theriogenology 54(5): 809-822.
Taylor MJ. 2006. Biology of cell survival in the cold: the basis for biopreservation of tissues and organs. Boca Raton, US. CRC Hlm. 1652 .

Tulake K, Yanagawa Y, Takahashi Y, Katagiri S, Higaki S, Koyama K, Wang X, Li H. 2014. Effects of ovarian storage condition on in vitro maturation of Hokkaido Sika deer (Cervus nippon yesoensis) oocytes. Jpn J Vet Res 62: 187-192.

Wiedemann C, Zahmel J, Jewgenow K. 2013. Short-term culture of ovarian cortex pieces to assess the cryopreservation outcome in wild felids for genome conservation. Vet Res 9(37): 1-11.

Wlodarczyk R, Bukowska D, Jackowska1 M, Mucha S, Jaskowski JM. 2009. In vitro maturation and degeneration of domestic cat oocytes collected from ovaries stored at various temperatures. Veterinarni Medicina 54(10): 491-497.

Wongsrikeao P, Otoi T, Karja NWK, Agung B, Nii M, Nagai T. 2005. Effect of ovary storage time and temperature on dna fragmentation and development of porcine oocytes. J Reprod Dev 51(1): 87-97. 